\title{
Analisis Periode Vernalisasi terhadap Keragaan Dua Tipe Bawang Putih di Dataran Rendah
}

\author{
Analysis of Vernalization Period on Two Type of Garlic in Lowland \\ Ainammardliyyah ${ }^{1}$, Sobir $^{1,2^{*}}$ \\ ${ }^{1}$ Departemen Agronomi dan Hortikultura, Fakultas Pertanian, Institut Pertanian Bogor (Bogor Agricultural University), \\ Jalan Meranti, Kampus IPB Darmaga, Bogor 16680, Indonesia. \\ ${ }^{2}$ Pusat Kajian Hortikultura Tropika, Lembaga Penelitian dan Pengabdian kepada Masyarakat Institut Pertanian Bogor, \\ Jl. Raya Pajajaran, Kampus IPB Baranangsiang, Bogor, Indonesia
}

Diterima 17 September 2018/Disetujui 22 Oktober 2018

\begin{abstract}
The aims of this research was to study the influence of vernalization period, garlic type and interaction of garlic type with vernalization period on garlic growth and bulbing in lowland. The research was conducted in experiment field PKHT, Bogor, West Java. This study used a factorial Randomized Complete Block Design (RCBD), garlic type (hardneck and softneck) and vernalization period (45 days, 30 days, and control). Hardneck garlic type has a higher number of leaves, speed germination, and bulbing percentage. Softneck garlic type has a higher sprouting percentage, percentage of live plants, leaf width and pseudo stem diameter. Vernalization promoted growth and bulbing of garlic. The interaction of softneck type of garlic with all periods of vernalization has a higher influence on percentage of live plants. The interaction of hardneck-45 day garlic and hardneck-30 day has a higher effect on the number of leaves. The number of leaves was positively correlated with bulb component and clove component.Planting garlic in the lowlandswas suitable for hardneck garlic type. Vernalization 30 day was effective to increase growth and yield of garlic in lowland.
\end{abstract}

Keywords: chilling, hardneck, softneck, storage period.

\section{ABSTRAK}

Penelitian ini bertujuan mempelajari pengaruh periode vernalisasi, tipe bawang putih serta interaksi tipe bawang putih dan periode vernalisasi terhadap pertumbuhan dan pengumbian bawang putih di dataran rendah. Penelitian dilaksanakan di Kebun Percobaan PKHT IPB, Bogor, Jawa Barat. Penelitian ini menggunakan Rancangan Kelompok Lengkap Teracak (RKLT) faktorial, yaitu tipe bawang putih (hardneck dan softneck) dan periode vernalisasi (45 hari, 30 hari, dan tanpa vernalisasi). Tipe bawang putih hardneck memiliki nilai lebih tinggi pada jumlah daun, kecepatan bertunas, dan persentase pengumbian. Tipe bawang putih softneck memiliki nilai lebih tinggi pada persentase bertunas, persentase tanaman hidup, lebar daun dan diameter batang semu. Perlakuan vernalisasi meningkatkan pertumbuhan dan pengumbian bawang putih. Interaksi tipe bawang putih softneck dengan semua periode vernalisasi memiliki pengaruh lebih tinggi pada persentase tanamanhidup. Interaksi tipe bawang putih hardneck-45 hari dan hardneck-30 hari memiliki pengaruh yang lebih tinggi pada jumlah daun. Jumlah daun berkorelasi positif dengan komponen umbi dan komponen siung.Penanaman bawang putih di dataran rendah sesuai untuk tipe bawang putih hardneck. Perlakuan vernalisasi selama 30 hari efektif untuk meningkatkan pertumbuhan dan hasil bawang putih di dataran rendah.

Kata kunci: hardneck, periode penyimpanan, perlakuan suhu dingin, softneck.

\section{PENDAHULUAN}

Bawang putih (Allium sativum L.) merupakan salah satu komoditas hortikultura yang memiliki peranan penting bagi masyarakat Indonesia.Umbi bawang putih banyak dimanfaatkan sebagai bumbu masak dan bahan obat-obatan.

* Penulis untuk korespondensi. e-mail: ridwanisobir@gmail.com
Produksi bawang putih di Indonesia pada tahun 2015 mencapai 20,293 ton dan terjadi peningkatan pada tahun 2016 menjadi 21,151 ton (BPS, 2016). Kebutuhan bawang putih yang tinggi di masyarakat belum dapat dipenuhi dari produksi domestik sehingga perlu dilakukan impor bawang putih.Menurut BPS (2017) Indonesia melakukan impor bawang putih sebesar 556,060 ton untuk memenuhi kebutuhan domestik. Sebesar $98 \%$ bawang putih tersebut diimpor dari negara China. 
Salah satu permasalahan bawang putih di Indonesia yaitu penurunan luas panen yang berakibat pada penurunan produksi bawang putih. Luas panen bawang putih mengalami penurunan dari tahun 2015 seluas 2,563 ha menjadi 2,407 ha di tahun 2016 (BPS, 2016).Penurunan luas panen bawang putih terjadi karena sentra bawang putih yang sebagian besar di dataran tinggi mengalami persaingan lahan dengan komoditas sayuran dataran tinggi lainnya. Penyebab lain rendahnya produksi bawang putih di Indonesia yaitu produktivitas rata-rata bawang putih di Indonesia yang hanya 8.79 ton/ha (BPS, 2016). Angka tersebut masih tergolong rendah jika dibandingkan China yang memiliki produktivitas rata-rata sebesar 25.34 ton/ ha (FAO, 2017).Salah satu upayauntuk meningkatkan produksi bawang putih dapat dilakukan dengan penanaman di dataran rendah yang ketersediaan lahannya masih banyak dibandingkan dataran tinggi.

Bawang putih terdiri atas dua tipe tanaman yaitu hardneck (Allium sativum ophioscorodon) dan softneck (Allium sativum sativum). Bawang putih tipe hardneck merupakan bawang putih yang mampu menghasilkan tangkai bunga (bolting). Ujung tangkai bunga akan tumbuh bulbil kecil, dimana ukuran dan jumlah bulbil yang dihasilkan bervariasi. Bawang putih tipe softneck merupakan bawang putih yang tidak menghasilkan tangkai bunga (non-bolting) (Allen, 2009) sehingga fotosintat teralokasi pada umbi (Orin, 2008).Bawang putih tersebut membutuhkan kondisi lingkungan yang sesuai untuk pertumbuhan dan perkembangannya. Menurut Brewster (2008) pada kondisi yang tidak sesuai, pengumbian bawang putih dapat tidak terjadi sehingga tanaman akan mengalami pertumbuhan vegetatif yang tidak terbatas. Pengumbian pada bawang putih diinisiasi oleh hari panjang dan suhu hangat. Wu et al. (2016) menambahkan bahwa panjang hari yang optimum untuk pembentukan umbi pada bawang putih yaitu 14 jam, sedangkan kebutuhan suhu hangat untuk pembentukan umbi bawang putih berbeda, tergantung pada masing-masing kultivar. Namun faktor tersebut tidak berpengaruh kecuali tanaman bawang putih telah terpapar suhu rendah, baik saat penyimpanan sebelum tanam atau di lapang setelah penanaman (Brewster, 2008). Dataran rendah tropis seperti di Indonesia tidak memiliki kondisi lingkungan dengan panjang hari (14 jam) dan suhu rendah $\left(5-10^{\circ} \mathrm{C}\right)$ di lapang yang dibutuhkan untuk pengumbian bawang putih. Sehingga alternatif yang dapat dilakukan yaitu dengan penyimpanan bahan tanam pada suhu dingin sebelum penanaman (vernalisasi). Brewster (2008) menambahkan bahwa selain mempengaruhi pengumbian, suhu penyimpanan umbi mempengaruhi kecepatan berkecambah setelah penanaman, vigor pertumbuhan dan bentuk tanaman setelah tumbuh.Siung yang sebelum penanamannya disimpan pada suhu $5-10^{\circ} \mathrm{C}$ dapat tumbuh dengan cepat dan menghasilkan tanaman dengan daun dan leher umbi yang lebar. Vernalisasi juga dapat berperan untuk mematahkan dormansi pada bawang putih.Hal ini bermanfaat untuk memperpendek masa dormansi bawang putih sehingga penanaman bawang putih dapat dilakukan lebih dari satu musim tanam dalam satu tahun. Penanaman bawang putih di dataran rendah perlu dilakukan dengan penggunaan tipe bawang putih dan perlakuan vernalisasi yang sesuai untuk meningkatkan produksi bawang putih di Indonesia. Penelitian ini bertujuan menganalisa pengaruh tipe bawang putih, periode vernalisasi, dan interaksi tipe bawang putih dan periode vernalisasi terhadap pertumbuhan dan pengumbian bawang putih di dataran rendah.

\section{BAHAN DAN METODE}

Penelitian dilaksanakan di Kebun Penelitian Pusat Kajian Hortikultura Tropika (PKHT), Pasir Kuda, Bogor, yang berada pada ketinggian 262 mdpl dan Laboratorium Pascapanen Departemen Agronomi dan Hortikultura, IPB. Penelitian dilaksanakan dari bulan September 2017 - Maret 2018.Bahan tanam yang digunakan yaitu bawang putih hardneck dan bawang putih softneck introduksi China.Umbi bawang putih yang dibutuhkan yaitu $1.8 \mathrm{~kg}$ bawang putih hardneck dan $2.48 \mathrm{~kg}$ bawang putih softneck. Media tanam yang digunakan yaitu tanah, pupuk kandang kambing, dan arang sekam. Bahan lain yang digunakan yaitu pupuk Urea, pupuk SP-36, pupuk KCl, pupuk ZA, pupuk NPK Phonska, pupuk $\mathrm{KSO}_{4}$, asam humat, kompos, dan kapur pertanian. Peralatan yang digunakan peralatan umum budidaya, bambu, label, plastik, polynet, timbangan, meteran, kulkas, termometer, dan jangka sorong.

Penelitian dilakukan dengan metode Rancangan Kelompok Lengkap Teracak (RKLT) Faktorial, dengan 2 faktor perlakuan. Faktor pertama yaitu tipe tanaman, terdiri atas 2 taraf yaitu $\mathrm{B}_{1}=$ bawang putih hardneck dan $\mathrm{B}_{2}=$ bawang putih softneck. Faktor kedua yaitu lama vernalisasi, terdiri atas 3 taraf yaitu $\mathrm{V}_{1}=45$ hari, $\mathrm{V}_{2}=30$ hari, $\mathrm{V}_{3}=$ tanpa vernalisasi. Perlakuan diulang sebanyak 3 ulangan, sehingga terdapat 18 satuan percobaan yang dapat diamati. Masing-masing satuan percobaan terdiri atas 50 tanaman.

Vernalisasi bahan tanam dilakukan menggunakan kulkas pada suhu $5-7^{\circ} \mathrm{C}$. Siung yang digunakan sebagai bahan tanam memiliki kriteria bebas hama dan penyakit, pangkal batang berisi penuh dan keras, siung bernas, serta memiliki bobot 1.5-3 g. Siung disimpan di kulkas menggunakan polynet plastik dan telah di pisahkan untuk bahan tanam masing-masing satuan percobaan. Penyimpanan dilakukan dalam 2 tahap, yaitu tahap pertama dilakukan pada bahan tanam dengan perlakuan 45 hari vernalisasi dan tahap kedua dilakukan pada bahan tanam dengan perlakuan 30 hari vernalisasi. Bahan tanam dengan perlakuan 45 hari vernalisasi mulai disimpan di dalam kulkas pada 45 hari sebelum tanggal penanaman, sedangkan bahan tanam dengan perlakuan 30 hari vernalisasi mulai disimpan di dalam kulkas pada 30 hari sebelum tanggal penanaman sehingga penanaman bahan tanam dapat dilakukan serentak di lapang. Siung dengan perlakuan periode vernalisasi 30 hari, sebelum memasuki tahap vernalisasi ditempatkan di kondisi suhu ruang. Bahan tanam dikeluarkan dari kulkas setelah periode vernalisasi dan dikeringanginkan.Bahan tanam dengan perlakuan tanpa vernalisasi disimpan dalam kondisi suhu ruang. Persiapan lahan dilakukan dengan membersihkan sisa-sisa tanaman sebelumnya yang berada 
di dalam atau di atas permukaan tanah dengan melakukan pencangkulan sedalam 20-30 $\mathrm{cm}$. Lahan percobaan berukuran $21 \mathrm{~m}^{2}$, yang terdiri atas 3 bedengan berukuran 1 x $7 \mathrm{~m}$. Pengaplikasian kapur, pupuk kandang, kompos, arang sekam, dan asam humat dilakukan 3 minggu sebelum penanaman. Setiap satuan percobaan memiliki ukuran 0.75 $\mathrm{m} \times 1 \mathrm{~m}$. Jarak tanam yang digunakan yaitu $15 \mathrm{~cm}$ x $10 \mathrm{~cm}$ dengan kedalaman $2-3 \mathrm{~cm}$. Pemberian pupuk Urea $(250 \mathrm{~kg} /$ ha) dan ZA (250 kg/ha) dilakukan 3 kali yaitu $20 \mathrm{HST}, 35$ HST, 50 HST. Pupuk SP-36 (200 kg/ha) diberikan sebagai pupuk dasar, $20 \mathrm{HST}$ dan $35 \mathrm{HST}$. Pupuk KCl (150 kg/ha) diberikan sebagai pupuk dasar, 20 HST dan 35 HST. Pupuk $\mathrm{KSO}_{4}(175 \mathrm{~kg} / \mathrm{ha})$ diberikan pada saat $50 \mathrm{HST}$ dan $65 \mathrm{HST}$. Pupuk NPK Phonska (70 kg/ha) diberikan setiap 1 minggu sekali dengan cara dikocor dengan konsentrasi (3 $\mathrm{g} / l$ ).

Kegiatan pemeliharaan meliputi penyiraman, penyiangan, pengendalian hama penyakit tanaman dan pemulsaan. Tanaman contoh untuk pengamatan ditentukan secara acak sebanyak 10 tanaman pada masing-masing satuan percobaan. Pengamatan dilakukan sesuai peubah pengamatan yang telah ditentukan terhadap 10 tanaman contoh.Pemanenan dilakukan secara bertahap hingga pemanenan akhir pada 114 HST. Ciri-ciri tanaman yang siap dipanen yaitu terjadi perubahan warna daun dari hijau menjadi kuning kecoklatan dengan tingkat kelayuan 35$60 \%$. Pemanenan dilakukan dengan mencabut tanaman kemudian daun dipotong, umbi dibersihkan dari sisa-sisa tanah.

Pengamatan dilakukan pada 10 tanaman contoh pada setiap satuan percobaan yang ditentukan secara acak. Peubah yang diamati dalam percobaan meliputi karakter vegetatif dan komponen hasil. Pengamatan karakter vegetatif dilakukan mulai 3 MST dengan interval 2 minggu yang meliputi tinggi tanaman $(\mathrm{cm})$, panjang daun $(\mathrm{cm})$, lebar daun $(\mathrm{cm})$, jumlah daun per tanaman dan diameter batang semu $(\mathrm{cm})$. Peubah lainnya yaitu persentasetase bertunas pada 1 MST dan persentase hidup tanaman pada 4 MST. Pengamatan komponen hasil dilakukan setelah pemanenan dengan peubah yang diamati meliputi bobot segar umbi per tanaman $(\mathrm{g})$, bobot kering umbi per tanaman $(\mathrm{g})$, diameter umbi $(\mathrm{cm})$, panjang umbi $(\mathrm{cm})$, jumlah siung per umbi, bobot rata-rata siung per umbi (g), panjang rata-rata siung per umbi $(\mathrm{cm})$, lebar rata-rata siung per umbi $(\mathrm{cm})$, dan bobot umbi per petak $(\mathrm{g})$.

\section{HASIL DAN PEMBAHASAN}

\section{Persentase Bertunas, Persentase Tanaman Hidup, Kecepatan Bertunas}

Tipe bawang putih dan periode vernalisasi sebagai faktor tunggal berpengaruh terhadap persentase bertunas, persentase tanaman hidup, dan kecepatan bertunas (Tabel 1). Tipe bawang putih softneck memiliki nilai persentase bertunas dan persentase tanaman hidup lebih tinggi dibandingkan tipe bawang putih hardneck. Hasil ini diduga dipengaruhi oleh dormansi dari umbi yang digunakan.Menurut Takagi (1990) bahwa siung bawang putih menjadi dorman ketika umbi mendekati kematangan. Dormansi paling kuat terjadi pada tahap matang sempurna dan panjangnya berbeda antar genotipe. Menurut Hsiao (2015) faktor-faktor yang mempengaruhi pematahan dormansi yaitu suhu penyimpanan, lama penyimpanan, kematangan saat umbi dipanen, dan kultivar. Dormansi pada umbi yang belum matang dapat dipatahkan dengan penyimpanan pada suhu $35^{\circ} \mathrm{C}$, sementara dormansi umbi yang matang sempurna dibutuhkan suhu $5-10^{\circ} \mathrm{C}$ (Takagi, 1990). Dormansi ini menyebabkan siung bawang putih tipe hardneck bertunas relatif tidakseragam, sedangkan tipe bawang putih softneck relatif lebih seragam.

Tabel 1 menunjukkan bahwa perlakuan vernalisasi mampu meningkatkan persentase bertunas dan persentase tanaman hidup. Hasil ini sesuai dengan pernyataan Youssef (2013) bahwa persentase bertunas siung bawang putih meningkat akibat pengaruh perlakuan vernalisasi sebelum tanam. Periode vernalisasi selama 45 hari dan 30 hari memberikan hasil yang tidak berbeda nyata. Hal ini menunjukkan bahwa periode vernalisasi melebihi 30 hari tidak mampu meningkatkan persentase bertunas dan persentase tanaman hidup pada tanaman bawang putih. Sehingga penggunaan periode vernalisasi selama 30 hari lebih efisien untuk meningkatkan persentase bertunas dan persentase tanaman hidup pada pertanaman bawang putih di dataran rendah.Namun hasil ini tidak sejalan dengan penelitian Resende et al. (2011) bahwa periode vernalisasi lebih efisien pada 40 hari. Hal ini dapat disebabkan adanya pengaruh kondisi lingkungan saat penyimpanan dan penanaman di lapang.

Kecepatan bertunas merupakan penambahan tanaman yang bertunas pada selang waktu 1 MST hingga 4 MST. Nilai kecepatan bertunas yang tinggi menunjukkan bahwa siung bawang putih membutuhkan waktu yang lebih lama untuk bertunas dan tidak seragam. Tipe bawang putih hardneck memiliki nilai kecepatan bertunas yang lebih tinggi dibandingkan bawang putih softneck (Tabel 1). Hal ini menunjukkan bahwa siung bawang putih hardneck tidak cepat dan tidak seragam dalam bertunas pada awal penanaman. Tipe bawang putih hardneck membutuhkan waktu yang lebih lama untuk dapat bertunas. Bawang putih softneck memiliki nilai kecepatan bertunas yang kecil. Hal ini menunjukkan bahwa, bawang putih softneck bertunas lebih cepat dan seragam pada awal pertanaman. Vernalisasi mampu mempercepat siung bawang putih untuk bertunas dan lebih seragam dalam bertunas dibandingkan tanpa vernalisasi (Tabel 1). Periode vernalisasi 45 hari dan 30 memiliki nilai kecepatan bertunas yang tidak berbeda nyata. Hal ini menunjukkan bahwa, periode vernalisasi 30 hari lebih efisien untuk meningkatkan siung untuk bertunas lebih cepat dan keseragaman dalam bertunas.

Interaksi tipe bawang putih dan periode vernalisasi berpengaruh sangat nyata terhadap persentase tanaman hidup, namun tidak berpengaruh nyata terhadap persentase bertunas dan kecepatan bertunas. Tabel 2 menunjukkan bahwa tipe tanaman softneck dengan periode vernalisasi selama 45 hari, 30 hari dan tanpa vernalisasi memiliki nilai persentase tanaman hidup tertinggi pada 4 MST. Nilai 
persentase tanaman hidup terkecil yaitu pada perlakuan tipe tanaman hardneck tanpa vernalisasi yang hanya sebesar 67.33\%. Hal ini menunjukkan bahwa tipe tanaman bawang putih softneck memiliki kemampuan bertunas lebih baik dan seragam meskipun tidak dilakukan perlakuan vernalisasi terhadap siung. Sedangkan tipe tanaman bawang putih hardneck memiliki kemampuan bertunas yang relatif tidak seragam. Perlakuan periode vernalisasi mampu meningkatkan persentase tanaman hidup pada tanaman tipe bawang putih hardneck. Periode vernalisasi selama 45 hari dan 30 hari memberikan hasil yang tidak berbeda nyata, jadi vernalisasi selama 30 hari lebih efisien digunakan untuk meningkatkan mempercepat kemunculan tunas dan meningkatkan persentase tanaman hidup pertanaman bawang putih tipe hardneck di dataran rendah.

\section{Tinggi Tanaman, Panjang Daun, Lebar Daun, Jumlah Daun, Diameter Batan Semu}

Data karakter vegetatif yang digunakan yaitu pada 7 MST yang merupakan pertumbuhan maksimum tanaman. Hasil pengamatan terhadap karakter vegetatif yang ditampilkan pada Tabel 3 menunjukkan bahwa tipe tanaman bawang putih tidak berpengaruh nyata terhadap karakter tinggi tanaman dan panjang daun. Namun berpengaruh nyata terhadap karakter lebar daun, jumlah daun, dan diameter batang semu. Nilai kisaran tinggi tanaman dan panjang daun pada tanaman tipe bawang putih hardneck berturutturut yaitu $37.52-64.51 \mathrm{~cm}$ dan $33.22-56.85 \mathrm{~cm}$. Nilai kisaran tinggi tanaman dan panjang daun pada tanaman tipe bawang putih softneck berturut-turut yaitu $44.77-67.91 \mathrm{~cm}$ dan 39.43 - $61.80 \mathrm{~cm}$. Tipe bawang putih hardneck memiliki jumlah daun yang lebih banyak dibandingkan tipe bawang putih softneck. Namun daun tanaman bawang putih tipe softneck lebih lebar dari daun tanaman bawang putih tipe hardneck. Hasil ini sejalan dengan pernyataan Orin (2008) bahwa tipe tanaman sotfneck memiliki daun yang lebih lebar dibandingkan tipe tanaman hardneck. Bawang putih tipe softneck memiliki diameter batang semu lebih besar dibandingkan bawang putih tipe hardneck.

Periode vernalisasi berpengaruh nyata terhadap tinggi tanaman, panjang daun, jumlah daun, lebar daun, dan diameter batang semu (Tabel 3). Tanaman dengan periode vernalisasi selama 30 dan 45 hari memiliki pertumbuhan vegetatif lebih tinggi dibandingkan tanaman tanpa vernalisasi.Hasil ini menunjukkan bahwa perlakuan vernalisasi dapat meningkatkan pertumbuhan tanaman bawang putih.Hal ini sejalan dengan pernyataan $\mathrm{Wu}$ et al. (2015) bahwa perlakuan vernalisasi dapat merangsang pertumbuhan tanaman terutama pertumbuhan pemanjangan tanaman.Peningkatan periode vernalisasi menjadi 45 hari tidak meningkatkan pertumbuhan vegetatif tanaman. Sehingga penggunaan periode vernalisasi selama 30 hari lebih efisien digunakan untuk meningkatkan pertumbuhan vegetatif bawang putih di dataran rendah.

Interaksi tipe bawang putih dan periode vernalisasi berpengaruh nyata hanya pada karakter jumlah daun (Tabel 4). Tanaman dengan jumlah daun terbanyak terdapat

Tabel 1. Nilai tengah persentase bertunas, persentase tanaman hidup, kecepatan bertunas perlakuan tipe bawang putih dan periode vernalisasi

\begin{tabular}{lccc}
\hline \multicolumn{1}{c}{ Perlakuan } & Persentase Bertunas (\%) & Persentase Tanaman Hidup (\%) & Kecepatan Bertunas (\%) \\
\hline Tipe bawang putih (B) & & & \\
\hline Hardneck & $23.78 \mathrm{~b}$ & $78.22 \mathrm{~b}$ & $54.44 \mathrm{a}$ \\
Softneck & $88.22 \mathrm{a}$ & $99.55 \mathrm{a}$ & $11.33 \mathrm{~b}$ \\
\hline Periode vernalisasi (V) & & & $23.00 \mathrm{~b}$ \\
\hline 45 hari & $68.67 \mathrm{a}$ & $91.66 \mathrm{a}$ & $26.33 \mathrm{~b}$ \\
30 hari & $65.33 \mathrm{a}$ & $91.66 \mathrm{a}$ & $49.33 \mathrm{a}$ \\
Tanpa vernalisasi & $34.00 \mathrm{~b}$ & $83.33 \mathrm{~b}$ & tn \\
Interaksi BxV & tn & $* *$ & \\
\hline
\end{tabular}

Keterangan : Angka yang diikuti huruf kecil yang sama pada masing-masing perlakuan menunjukkan tidak berbeda nyata berdasarkan uji lanjut Duncan Multiple Range Test (DMRT) pada taraf $\alpha=5 \%$.

Tabel 2. Pengaruh interaksi tipe bawang putih dan periode vernalisasi terhadap persentase tanaman hidup

\begin{tabular}{lccc}
\hline \multirow{2}{*}{ Tipe Bawang Putih } & \multicolumn{3}{c}{ Periode Vernalisasi } \\
\cline { 2 - 4 } & 45 hari & 30 hari & Tanpa vernalisasi \\
\hline Hardneck & $83.33 \mathrm{~b}$ & $84.00 \mathrm{~b}$ & $67.33 \mathrm{c}$ \\
Softneck & $100.00 \mathrm{a}$ & $99.33 \mathrm{a}$ & $99.33 \mathrm{a}$ \\
\hline
\end{tabular}

Keterangan : Angka yang diikuti huruf kecil yang sama menunjukkan tidak berbeda nyata berdasarkan uji lanjut Duncan Multiple Range Test (DMRT) pada taraf $\alpha=5 \%$. 
pada perlakuan tipe tanaman bawang putih hardneck dengan periode vernalisasi 30 dan 45 hari yaitu 5 helai daun. Perlakuan tipe tanaman bawang putih hardneck tanpa vernalisasi (suhu ruang) dan tipe tanaman bawang putih softneck pada semua perlakuan periode vernalisasi memberikan pengaruh yang sama terhadap karakter jumlah daun. Hal ini menunjukan bahwa pada tipe tanaman bawang putih hardneck penambahan perlakuan vernalisasi mampu meningkatkan jumlah daun yang dihasilkan tanaman. Sedangkan pada tipe tanaman bawang putih softneck penambahan perlakuan vernalisasi tidak berpengaruh terhadap jumlah daun yang dihasilkan.

\section{Persentase Pengumbian}

Tipe bawang putih berpengaruh nyata terhadap persentase pengumbian.Persentase pengumbian pada tipe bawang putih hardneck lebih tinggi dibandingkan bawang putih tipe softneck yaitu sebesar 52.44\% (Tabel 5). Tanaman tipe bawang putih softneck memiliki pertumbuhan awal yang lebih tinggi dibandingkan tipe bawang putih hardneck, namun tipe bawang putih softneck hanya memiliki persentase pengumbian sebesar $1.33 \%$. Oleh sebab itu, tipe bawang putih softneck tidak dapat dilakukan pengukuran komponen hasil lainnya seperti bobot basah umbi per tanaman, bobot kering umbi per tanaman, diameter umbi, panjang umbi, bobot umbi per petak, jumlah siung per umbi, bobot siung per umbi, panjang siung per umbi, dan lebar siung per umbi. Pada sebagian besar tanaman yang tidak berumbi menunjukkan tanda masih berlangsungnya proses pertumbuhan (Gambar 1). Hal ini diduga disebabkan karena kebutuhan panjang hari yang tidak terpenuhi untuk menginisiasi pengumbian pada bawang putih softneck meskipun telah dilakukan vernalisasi sehingga tanaman tetap berada pada fase pertumbuhan vegetatif.Kebutuhan panjang hari yang optimum untuk pembentukan umbi pada bawang putih yaitu 14 jam (Wu et al., 2016) Rubatzky dan Yamaguchi (1998) menambahkan bahwa suhu berinteraksi dengan fotoperiode selama pembesaran umbi.Kebutuhan panjang hari dapat diperpendek dengan pemaparan terhadap suhu rendah yang berkelanjutan.Hasil ini menunjukkan bahwa tipe bawang putih hardneck lebih sesuai untuk ditanam di dataran rendah dibandingkan tipe bawang putih softneck.

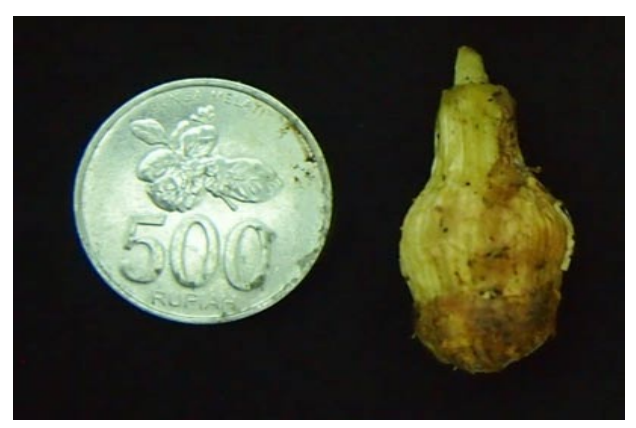

Gambar 1. Tanaman yang proses pertumbuhannya masih berlangsung

Tabel 3. Nilai tengah karakter vegetatif perlakuan tipe bawang putih dan periode vernalisasi

\begin{tabular}{|c|c|c|c|c|c|}
\hline Perlakuan & $\mathrm{TT}(\mathrm{cm})$ & $\mathrm{PD}(\mathrm{cm})$ & $\mathrm{LD}(\mathrm{cm})$ & JD (helai) & DBS (mm) \\
\hline \multicolumn{6}{|l|}{ Tipe bawang putih (B) } \\
\hline Hardneck & 51.1 & 44.98 & $1.10 \mathrm{~b}$ & $4.6 \mathrm{a}$ & $5.98 b$ \\
\hline Softneck & 57.24 & 51.41 & $1.40 \mathrm{a}$ & $4.1 \mathrm{~b}$ & $6.95 \mathrm{a}$ \\
\hline \multicolumn{6}{|l|}{ Periode vernalisasi (V) } \\
\hline 45 hari & $59.02 \mathrm{a}$ & 52.43 & $1.38 \mathrm{a}$ & $4.5 \mathrm{a}$ & $6.77 \mathrm{a}$ \\
\hline 30 hari & $57.58 \mathrm{a}$ & 49.27 & $1.25 \mathrm{ab}$ & $4.6 \mathrm{a}$ & $6.77 \mathrm{a}$ \\
\hline Tanpa vernalisasi & $45.98 b$ & 42.88 & $1.12 \mathrm{~b}$ & $4.0 \mathrm{~b}$ & $5.85 b$ \\
\hline Interaksi BxV & tn & tn & tn & $*$ & tn \\
\hline
\end{tabular}

Keterangan : Angka yang diikuti huruf kecil yang sama pada masing-masing perlakuan menunjukkan tidak berbeda nyata berdasarkan uji lanjut Duncan Multiple Range Test (DMRT) pada taraf $\alpha=5 \%, *=$ berpengaruh nyata pada taraf $5 \%$, th $=$ tidak berpengaruh nyata, $\mathrm{TT}=$ tinggi tanaman, $\mathrm{PD}=$ panjang daun, $\mathrm{LD}=$ lebar daun, $\mathrm{JD}=$ jumlah daun, $\mathrm{DBS}=$ diameter batang semu.

Tabel 4. Pengaruh interaksi perlakuan tipe bawang putih dan periode vernalisasi terhadap jumlah daun

\begin{tabular}{lccc}
\hline \multirow{2}{*}{ Tipe Bawang Putih } & \multicolumn{3}{c}{ Periode Vernalisasi } \\
\cline { 2 - 4 } & 45 hari & 30 hari & Tanpa vernalisasi \\
\hline Hardneck & $5.0 \mathrm{a}$ & $5.0 \mathrm{a}$ & $4.0 \mathrm{~b}$ \\
Softneck & $4.0 \mathrm{~b}$ & $4.3 \mathrm{~b}$ & $4.0 \mathrm{~b}$ \\
\hline
\end{tabular}

Keterangan : Angka yang diikuti huruf kecil yang sama menunjukkan tidak berbeda nyata berdasarkan uji lanjut Duncan Multiple Range Test (DMRT) pada taraf $\alpha=5 \%$. 
Periode vernalisasi tidak berpengaruh nyata terhadap persentase pengumbian (Tabel 5). Hasil ini menunjukkan bahwa perlakuan vernalisasi tidak mempengaruhi pengumbian pada bawang putih di dataran rendah.Hasil ini bertentangan dengan pernyataan Brewster (2008) bahwa bawang putih memerlukan paparan suhu rendah untuk menginisiasi pengumbian. Namun berdasarkan hasil yang didapatkan, pengumbian pada bawang putih tetap dapat terjadi pada tanaman yang ditanam di dataran rendah tanpa vernalisasi.Siung tanpa vernalisasi tidak mendapatkan paparan suhu rendah baik selama saat penyimpanan maupun selama pertumbuhan di lapang, dimana menurut BMKG (2018) suhu minimum dari bulan November 2017 - Maret 2018 adalah $19.5^{\circ} \mathrm{C}$.

Bobot Basah Umbi per Tanaman, Bobot Kering Umbi per Tanaman, Diameter Umbi, Panjang Umbi, Bobot Umbi per Petak

Periode vernalisasi berpengaruh nyata terhadap bobot basah umbi per tanaman, bobot kering umbi per tanaman, diameter umbi, panjang umbi, bobot umbi per petak (Tabel 6). Perlakuan vernalisasi mampu meningkatkan komponen hasil umbi dibandingkan tanpa perlakuan vernalisasi. Periode vernalisasi selama 45 dan 30 hari memiliki pengaruh yang sama terhadap bobot dan ukuran umbi yang dihasilkan. Pemanjangan periode vernalisasi melebihi 30 hari tidak menunjukkan adanya peningkatan pada bobot dan ukuran umbi yang dihasilkan.Sehingga penggunaan periode vernalisasi selama 30 hari lebih efisien digunakan untuk meningkatkan hasil umbi pertanaman bawang putih di dataran rendah. Menurut Bandara et al. (1999) periode vernalisasi selama 45 hari memberikan hasil yang lebih tinggi dibandingkan selama 30 hari, serta peningkatan periode vernalisasi lebih dari 45 hari menyebabkan penurunan terhadap umbi yang dihasilkan. Wu et al. (2015)

Tabel 5. Nilai tengah persentase pengumbian perlakuan tipe bawang putih dan periode vernalisasi

\begin{tabular}{|c|c|}
\hline Perlakuan & Persentase Pengumbian (\%) \\
\hline \multicolumn{2}{|c|}{ Tipe bawang putih (B) } \\
\hline Hardneck & $52.44 \mathrm{a}$ \\
\hline Softneck & $1.33 \mathrm{~b}$ \\
\hline \multicolumn{2}{|c|}{ Periode vernalisasi (V) } \\
\hline 45 hari & 31.33 \\
\hline 30 hari & 29.33 \\
\hline Tanpa vernalisasi & 20 \\
\hline Interaksi BxV & tn \\
\hline
\end{tabular}

Keterangan: Angka yang diikuti huruf kecil yang sama menunjukkan tidak berbeda nyata berdasarkan uji lanjut Duncan Multiple Range Test (DMRT) pada taraf $\alpha=5 \%$, th $=$ tidak berbeda nyata pada uji $\mathrm{F}$ pada $\operatorname{taraf} \alpha=5 \%$. menambahkan bahwa pemanjangan durasi dan suhu yang rendah pada perlakuan vernalisasi menurunkan hasil dan bobot umbi yang dihasilkan.

Periode vernalisasi tidak berpengaruh terhadap persentase pengumbian pada bawang putih, namun periode vernalisasi mampu meningkatkan ukuran dan bobot umbi bawang putih yang dihasilkan.Umbi dari tanaman dengan periode vernalisasi selama 45 dan 30 hari memiliki ukuran dan bobot yang lebih tinggi dibandingkan umbi dari tanaman tanpa vernalisasi.Umbi yang dihasilkan dari perlakuan periode vernalisasi selama 30 hari memiliki nilai diameter umbi dan panjang umbi yang lebih besar dibandingkan umbi dengan periode vernalisasi selama 45 hari.Namun nilai bobot kering umbi per tanaman dan bobot umbi per petak yang dihasilkan lebih kecil dibandingkan umbi dengan periode vernalisasi selama 45 hari.Hal ini diduga karena ketidakbernasan umbi yang dihasilkan dari perlakuan periode vernalisasi selama 30 hari.

Jumlah Siung per Umbi, Bobot Siung per Umbi, Panjang Siung per Umbi, Lebar Siung per Umbi

Umbi bawang putih yang dihasilkan membentuk umbi tunggal, hanya pada beberapa umbi masing-masing perlakuan periode vernalisasi yang menghasilkan siung, meskipun siung yang terbentuk tidak sempurna (Gambar 3). Siung yang tidak sempurna terbentuk dikarenakan tidak tercapainya kondisi yang sesuai untuk pembentukan siung. Siung bawang putih yang ditanam, pada awal penanamannya mendapatkan paparan suhu tinggi dan hari pendek. Hal ini diduga sebagai penyebab terjadinya pembentukan umbi tunggal pada tanaman bawang putih pada semua perlakuan periode vernalisasi. Menurut Brewster (2008) pembentukan siung pada bawang putih dapat terjadi apabila percabangan tunas aksilar terjadi sebelum daun lumbung terdiferensiasi. Percabangan tunas aksilar dapat terjadi jika setelah penanaman siung terpapar kondisi suhu dingin dan hari yang pendek. Setelah terjadi percabangan tunas aksilar,

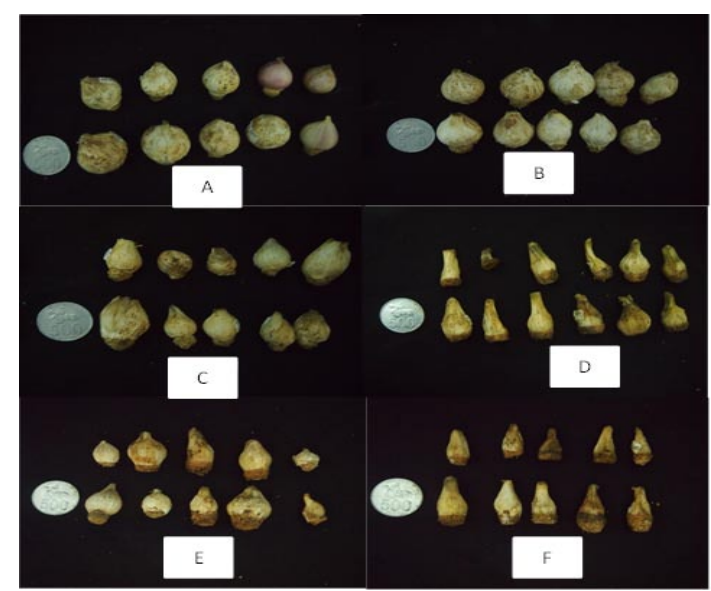

Gambar 2. Umbi bawang putih $\mathrm{A}=$ hardneck -45 hari, $\mathrm{B}=$ hardneck -30 hari, $\mathrm{C}=$ hardneck -tanpa vernalisasi, $\mathrm{D}=$ softneck -45 hari, $\mathrm{E}=$ softneck -30 hari, $\mathrm{F}=$ softneck - tanpa vernalisasi 
peningkatan suhu dan hari panjang dibutuhkan untuk meningkatkan diferensiasi daun lumbung dan pertumbuhan umbi bersiung normal. Namun apabila setelah penanaman, siung bawang putih terpapar suhu tinggi dan hari panjang maka akan mendorong diferensiasi daun lumbung lebih cepat sehingga siung terbentuk sebelum tunas aksilar bercabang dan menghasilkan umbi tunggal.

Periode vernalisasi tidak berpengaruh nyata terhadap jumlah siung bawang putih tipe hardneck (Tabel 7). Periode vernalisasi berpengaruh nyata terhadap karakter bobot siung per umbi, panjang siung per umbi, dan lebar siung per umbi (Tabel 7). Perlakuan vernalisasi mampu meningkatkan bobot siung per umbi, panjang siung per umbi, lebar siung per umbi dibandingkan tanpa vernalisasi.Periode vernalisasi selama 45 dan 30 hari memberikan hasil yang tidak berbeda nyata. Pemanjangan periode vernalisasi melebihi 30 hari tidak menunjukkan peningkatan pada bobot dan ukuran siung yang dihasilkan, sehingga perlakuan vernalisasi selama 30 hari efisien digunakan untuk meningkatkan komponen hasil siung bawang putih di dataran rendah.

Penanaman bawang putih introduksi dari China di dataran rendah tidak menunjukkan pertumbuhan dan hasil umbi yang lebih baik jika dibandingkan dengan bawang putih dataran rendah lokal yaitu varietas Lumbu Putih. Hal ini diduga disebabkan kondisi lingkungan yang kurang sesuai untuk pertumbuhan dan pengumbian pada bawang putih introduksi China. Namun perlakuan vernalisasi menunjukkan mampu meningkatkan pertumbuhan dan pengumbian pada bawang putih di dataran rendah.

Analisis Korelasi
Analisis korelasi menunjukan hubungan karakter kuantitatif pada bawang putih hardneck (Tabel 8). Persentase bertunas, persentase tanaman hidup dan persen pengumbian berkorelasi positif satu sama lain. Kecepatan bertunas berkorelasi negatif dengan persentase pengumbian. Hal ini menunjukkan bahwa ketidakseragaman siung dalam bertunas akan menurunkan tanaman yang berumbi. Karakter vegetatif tanaman seperti tinggi tanaman, panjang daun, lebar daun, dan diameter batang semu saling berkorelasi

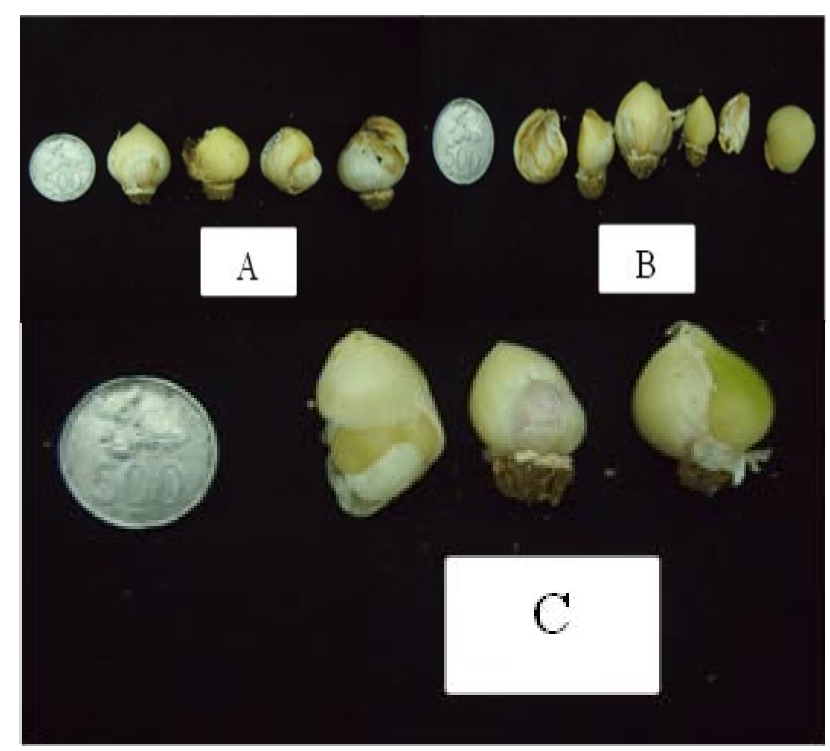

Gambar 3. Umbi dengan siung tidak sempurna $\mathrm{A}=$ hardneck -45 hari, $\mathrm{B}=$ hardneck -30 hari, $\mathrm{C}=$ hardneck -tanpa vernalisasi

Tabel 6. Nilai tengah komponen hasil (umbi) perlakuan tipe bawang putih hardneck dan periode vernalisasi

\begin{tabular}{lccccc}
\hline \multicolumn{1}{r}{ Perlakuan } & BBUT $(\mathrm{g})$ & BKUT $(\mathrm{g})$ & DU $(\mathrm{mm})$ & PU $(\mathrm{mm})$ & BUP $(\mathrm{g})$ \\
\hline Periode vernalisasi $(\mathrm{V})$ & & & & & \\
45 hari & $6.95 \mathrm{a}$ & $5.08 \mathrm{a}$ & $20.12 \mathrm{a}$ & $21.82 \mathrm{a}$ & $157.61 \mathrm{a}$ \\
30 hari & $6.88 \mathrm{a}$ & $4.80 \mathrm{a}$ & $22.05 \mathrm{a}$ & $24.79 \mathrm{a}$ & $135.33 \mathrm{a}$ \\
Tanpa vernalisasi & $3.53 \mathrm{~b}$ & $2.34 \mathrm{~b}$ & $14.59 \mathrm{~b}$ & $17.44 \mathrm{~b}$ & $45.92 \mathrm{~b}$ \\
\hline
\end{tabular}

Keterangan : Angka yang diikuti huruf kecil yang sama pada masing-masing perlakuan menunjukkan tidak berbeda nyata berdasarkan uji lanjut Duncan Multiple Range Test (DMRT) pada taraf $\alpha=5 \%$. BBUT $=$ Bobot basah umbi per tanaman, BKUT $=$ bobot kering umbi per tanaman, $\mathrm{DU}=$ diameter umbi, $\mathrm{PU}=$ panjang umbi, $\mathrm{BUP}=$ bobot umbi per petak

Tabel 7. Nilai tengah komponen hasil (siung) perlakuan tipe bawang putih hardneck dan periode vernalisasi

\begin{tabular}{lcccc}
\hline \multicolumn{1}{c}{ Perlakuan } & JSU (siung) & BSU (g) & PSU (mm) & LSU (mm) \\
\hline Periode vernalisasi (V) & 1 & & & \\
45 hari & 1 & $5.08 \mathrm{a}$ & $21.81 \mathrm{a}$ & $20.12 \mathrm{a}$ \\
30 hari & 1 & $4.80 \mathrm{a}$ & $24.60 \mathrm{a}$ & $21.87 \mathrm{a}$ \\
Tanpa vernalisasi & 1 & $2.30 \mathrm{~b}$ & $17.26 \mathrm{~b}$ & $14.45 \mathrm{~b}$ \\
\hline
\end{tabular}

Keterangan : Angka-angka yang diikuti huruf kecil yang sama pada masing-masing perlakuan menunjukkan tidak berbeda nyata JSU = Jumlah siung per umbi, BSU = bobot siung per umbi, PSU = panjang siung per umbi, LSU = lebar siung per umbi 
Tabel 8. Korelasi antar karakter kuantitatif tipe hardneck dan periode vernalisas

\begin{tabular}{|c|c|c|c|c|c|c|c|c|c|c|c|c|c|c|c|c|}
\hline & PB & PTH & KB & TT & PD & LD & JD & DBS & $\mathrm{PP}$ & BBUT & BKUT & DU & $\mathrm{PU}$ & BUP & BSU & $\begin{array}{ll}\text { JSU } & \text { PSU }\end{array}$ \\
\hline PTH & $0.94^{* *}$ & & & & & & & & & & & & & & & \\
\hline KB & $-0.96^{* *}$ & $-0.82^{* *}$ & & & & & & & & & & & & & & \\
\hline $\mathrm{TT}$ & $0.57^{\mathrm{tn}}$ & $0.64^{\mathrm{tn}}$ & $-0.46^{\text {th }}$ & & & & & & & & & & & & & \\
\hline PD & $0.45^{\mathrm{tn}}$ & $0.54^{\mathrm{tn}}$ & $-0.33^{\text {th }}$ & $0.99^{* *}$ & & & & & & & & & & & & \\
\hline LD & $0.42^{\text {tn }}$ & $0.48^{\text {tn }}$ & $-0.34^{\text {th }}$ & $0.90^{* *}$ & $0.92^{* *}$ & & & & & & & & & & & \\
\hline JD & $0.92^{* *}$ & $0.95^{* *}$ & $-0.82^{* *}$ & $0.67^{\text {tn }}$ & $0.52^{\mathrm{tn}}$ & $0.42^{\text {tn }}$ & & & & & & & & & & \\
\hline DBS & $0.59^{\text {tn }}$ & $0.61^{\mathrm{tn}}$ & $-0.53^{\text {tn }}$ & $0.94^{* *}$ & $0.93^{* *}$ & $0.94^{* *}$ & $0.56^{\mathrm{tn}}$ & & & & & & & & & \\
\hline PP & $0.81^{* *}$ & $0.69^{*}$ & $-0.83^{* *}$ & $0.17^{\text {tn }}$ & $0.05^{\text {tn }}$ & $0.04^{\mathrm{tn}}$ & $0.71^{*}$ & $0.22^{\mathrm{tm}}$ & & & & & & & & \\
\hline BBUT & $0.92^{* *}$ & $0.87^{* *}$ & $-0.89^{* *}$ & $0.76^{*}$ & $0.66^{\mathrm{tn}}$ & $0.55^{\text {tn }}$ & $0.92^{* *}$ & $0.72^{*}$ & $0.63^{\text {th }}$ & & & & & & & \\
\hline BKUT & $0.96^{* *}$ & $0.88^{* *}$ & $-0.94^{* *}$ & $0.65^{\text {tn }}$ & $0.54^{\text {tn }}$ & $0.46^{\mathrm{tn}}$ & $0.92^{* *}$ & $0.66^{\mathrm{tn}}$ & $0.75^{*}$ & $0.97^{* *}$ & & & & & & \\
\hline DU & $0.80^{*}$ & $0.78^{*}$ & $-0.75^{*}$ & $0.72^{*}$ & $0.63^{\text {tn }}$ & $0.42^{\text {tn }}$ & $0.87^{* *}$ & $0.59^{\text {tn }}$ & $0.57^{\text {tn }}$ & $0.92^{* *}$ & $0.89^{* *}$ & & & & & \\
\hline PU & $0.70^{*}$ & $0.68^{*}$ & $-0.65^{\text {tn }}$ & $0.64^{\mathrm{tn}}$ & $0.55^{\text {tn }}$ & $0.30^{\text {tn }}$ & $0.81^{* *}$ & $0.46^{\text {tn }}$ & $0.48^{\text {tn }}$ & $0.87^{* *}$ & $0.81^{* *}$ & $0.97^{* *}$ & & & & \\
\hline BUP & $0.97^{* *}$ & $0.87^{* *}$ & $-0.98^{* *}$ & $0.47^{\text {tn }}$ & $0.34^{\text {tn }}$ & $0.30^{\operatorname{tn}}$ & $0.89^{* *}$ & $0.51^{\text {tn }}$ & $0.90^{* *}$ & $0.89^{* *}$ & $0.96^{* *}$ & $0.78^{*}$ & $0.69^{*}$ & & & \\
\hline BSU & $0.96^{* *}$ & $0.89^{* *}$ & $-0.94^{* *}$ & $0.66^{\mathrm{tn}}$ & $0.55^{\text {tn }}$ & $0.47^{\mathrm{tn}}$ & $0.92^{* *}$ & $0.67^{*}$ & $0.74^{*}$ & $0.98^{* *}$ & $1.00^{* *}$ & $0.89^{* *}$ & $0.81^{* *}$ & $0.96^{* *}$ & & \\
\hline JSU & $-0.26^{\text {th }}$ & $-0.27^{\text {tn }}$ & $0.24^{\mathrm{tn}}$ & $-0.21^{\text {tn }}$ & $-0.19^{\mathrm{tn}}$ & $-0.34^{t}$ & $-0.20^{\text {th }}$ & ${ }^{n}-0.26^{\text {th }}$ & $0.02^{\text {tn }}$ & $-0.26^{\mathrm{tn}}$ & $-0.14^{\text {th }}$ & $0.06^{\text {tn }}$ & $0.03^{\text {tn }}$ & $-0.12^{\text {th }}$ & $-0.16^{\mathrm{tn}}$ & \\
\hline PSU & $0.71^{*}$ & $0.70^{*}$ & $-0.66^{\text {tn }}$ & $0.65^{\text {tn }}$ & $0.56^{\text {tn }}$ & $0.33^{\text {tn }}$ & $0.83^{* *}$ & $0.48^{\text {tn }}$ & $0.48^{\text {tn }}$ & $0.88^{* *}$ & $0.86^{* *}$ & $0.97^{* *}$ & $1.00^{* *}$ & $0.70^{*}$ & $0.82^{* *}$ & $-0.04^{\text {tn }}$ \\
\hline LSU & $0.82^{* *}$ & $0.80^{*}$ & $-0.76^{*}$ & $0.73^{*}$ & $0.64 \mathrm{t}^{\mathrm{n}}$ & $0.44^{\mathrm{tn}}$ & $0.88^{* *}$ & $0.60^{\text {tn }}$ & $0.57^{\text {tn }}$ & $0.94^{* *}$ & $0.90^{* *}$ & $1.00^{* *}$ & $0.97^{* *}$ & $0.79^{*}$ & $0.90^{* *}$ & $-0.00^{\operatorname{tn}} 0.97^{* *}$ \\
\hline
\end{tabular}

Keterangan : $\quad \mathrm{PB}=$ persentase bertunas, $\mathrm{PTH}=$ persentase tanaman hidup, $\mathrm{KB}=$ kecepatan bertunas, $\mathrm{TT}=$ tinggi tanaman, $\mathrm{PD}=$ panjang daun, $\mathrm{LD}=$ lebar daun, $\mathrm{JD}=$ jumlah daun, $\mathrm{DBS}=$ diameter batang semu, $\mathrm{PP}=$ persentase pengumbian, $\mathrm{BBUT}=$ bobot basah umbi per tanaman, BKUT = bobot kering umbi per tanaman, DU = diameter umbi, $\mathrm{PU}=$ panjang umbi, BUP = bobot umbi per plot, BSU = bobot siung per umbi, JSU= jumlah siung per umbi, $\mathrm{PSU}=$ panjang siung per umbi, $\mathrm{tn}=\mathrm{tidak}$ berkorelasi, ${ }^{*}=$ berkorelasi nyata pada taraf $5 \%,{ }^{* *}=$ berkorelasi nyata pada taraf $1 \%$

positif satu sama lain, kecuali pada karakter jumlah daun yang tidak berkorelasi. Jumlah daun berkorelasi positif dengan komponen umbi (bobot basah umbi per tanaman, bobot kering umbi per tanaman, diameter umbi, panjang umbi, bobot umbi per petak) dan komponen siung (bobot siung per umbi, panjang siung per umbi dan lebar siung per umbi). Hal ini menunjukkan bahwa komponen umbi dan siung bawang putih meningkat seiring peningkatan jumlah daun pada tanaman. Korelasi positif lain juga ditunjukkan pada hubungan komponen umbi dan komponen siung kecuali pada karakter jumlah siung per umbi. Jumlah siung per umbi tidak berkorelasi dengan semua karakter yang diamati, baik karakter vegetatif maupun komponen hasil.

\section{KESIMPULAN}

Tipe bawang putih hardneck memiliki jumlah daun yang lebih banyak dan persentase pengumbian yang lebih tinggi.Tipe bawang putih softneck memiliki persentase bertunas, persentase hidup tanaman, lebar daun dan diameter batang semu yang lebih tinggi.

Periode vernalisasi selama 45 hari dan 30 hari memiliki pengaruh yang sama dan menunjukkan hasil yang lebih tinggi dari perlakuan tanpa vernalisasi pada persentase bertunas, persentase tanaman hidup, tinggi tanaman, lebar daun, jumlah daun, diameter batang semu, bobot basah umbi per tanaman, bobot kering umbi per tanaman, panjang umbi, diameter umbi, panjang siung per umbi, lebar siung, bobot siung per umbi dan bobot umbi per petak.

Tipe bawang putih softneck yang divernalisasi selama 45 hari, 30 hari maupun tanpa vernaliasi memiliki persentase bertunas yang lebih tinggi. Tipe bawang putih hardneck yang divernalisasi selama 45 hari dan 30 hari memiliki jumlah daun yang lebih banyak.Jumlah daun berkorelasi positif dengan komponen umbi dan komponen siung

\section{DAFTAR PUSTAKA}

Allen, J. 2009. Garlic production.FACTSHEET. http:// www.omafra.gov.on.ca/english/crops/facts/09-011w. htm [2018 Juni 23].

Bandara, M.S., K. Krieger, A.E. Slinkard, K.K. Tanino. 1999. Pre-plant chilling requirements for cloving of spring-planted garlic. J. Plant Sci. 80: 379-384.

[BMKG] Badan Meteorologi, Klimatologi, dan Geofisika. 2018. Data Klimatologi untuk Bulan November 2017 hingga Bulan Maret 2018 di Bogor. BMKG Dramaga, Bogor. 
[BPS] Badan Pusat Statistik. 2016. Statistik Tanaman Sayuran dan Buah-buahan Semusim. Badan Pusat Statistik. Jakarta. https://www.bps.go.id/publication/ 2017/10/02/9d10a13049cee1ce8aad9768/statistiktanaman-sayuran-dan-buah-buahan-semusimindonesia-2016.html [11 Desember 2017].

[BPS] Badan Pusat Statistik. 2017. Statistik Perdagangan Luar Negeri: Impor Jilid 1. Badan Pusat Statistik. Jakarta. https:/www.bps.go.id/publication/ 2018/06 /08/2b6e651760870a4ce467f3aa/direktori-importirindonesia-2017-jilid-i.html [23 Juni 2018].

Brewster J.L. 2008. Onions and Other Vegetable Alliums, 2nd Edition. CAB International, Wallingford.

[FAO] Food and Agriculture Organization. 2014. Production/ Yield Quantities of Garlic in China. https://www.fao. org/faostat/\#data/QC/visualize. [11 Desember 2017].

Hsiao, J. 2015. Calibration, validation and improvement of a process-based crop simulation model for hardneck garlic (Allium sativum L.). Tesis.University of Washington.

Orin, M. 2008. A Garlic Primer.For the Gardener Series. http://escholarship.org/uc/item/9b67x6nm[2 Oktober 2017]
Resende, J.T.V., R.G.F. Morales, F.V. Resende, M.V. Faria, R.J. Souza, A. Marchese. 2011. Garlic vernalization and planting dates in Guarapuava. Horticultura Brasileira 29: 193-198.

Rubatzky, V.E., M. Yamaguchi. 1998. Sayuran Dunia: Prinsip, Produksi dan Gizi, Jilid 2. C. Herison, penerjemah. ITB Press, Bandung. Terjemahan dari: Vegetables: Principles, Production, and Nutritive Values, Second Edition.

Takagi, H. 1990. Garlic Allium sativum L. In: Rabinowitch, H.D. (Ed.), Onions and Allied Crops Biochemical Food Science Minor Crops: v. 3. CRC Press, Boca Raton, FL.

Wu, C., M. Wang, Y. Dong, Z. Cheng, H. Meng. 2015. Growth, bolting and yield of garlic (Allium sativum L.) in response to clove chilling treatment. Sci. Hortic. 194: 43-52.

Wu, C., M. Wang, Z. Cheng, H. Meng. 2016. Response of garlic (Allium sativum L.) bolting and bulbing to temperature and photoperiod treatments. Biologi Open 5: 507-518.

Youssef, N.S. 2013. Growth and bulbing of garlic as influenced by low temperature and storage period treatments. World Rural Observations 5(2):47-57. 